\title{
Fostering Public Army Relation in Nepal
}

\section{Eak Prasad Duwadi}

\section{Abstract}

Nepal maintained army strength even during the reigns of Lichchavi kings. Later, its operations began to generate income. The way in which King Prithvi Narayan Shah and his successors diligently mastered the art of warfare and strategy resulted in the success of the Gorkhali army. After the Kot Prava, the Rana family emerged and radically changed policies. This research studies on Nepali Army's glorious history, transformation, and mainly its public relation. The Postmodern Military Model (PMMM) is the theoretical perspective that has guided this study. For this, a qualitative method that deals with subjectivity is adopted. Secondary data such as journals, books and standard websites are used to analyze the data. Nepali Army is not a threat to the society that it protects as it has been trying to build its trust and credibility among the public. During its Imperial Era, the Great Britain awarded several Grukha soldiers in its military the 'Victoria Cross' for their unparalleled bravery and courage in various battles. Nepali Army gets exposure to serve in the outside world for decades. Relation between civil and army has not been bad in Nepal for many centuries despite of having some rubbings in the modern Nepal. However, politicians, notably the sitting PM or Defense Minister, routinely try to invoke the Nepal Army and draw it into the political jurisdiction. Nepali Army has been doing its duties honestly and unfailingly both inside and outside Nepal.

Keywords: Nepali Army, civilians, bravery, Gorkhali, honesty

\section{Introduction}

War of words between Nepali Army and public is hardly seen until now because it often sticks to its guns. Nepali Army claims they are doing what they are required to do, not only in terms of submitting to civilian control, but also in successfully filling the current very wide spectrum of roles and missions assigned inside and outside of Nepal. Relation between society and the Nepal Army is a pertinent topic that both internal and external readers are very much interested to know. Affinities between civil and Nepali Army may not be excellent nor bad, but good. In Nepal for many centuries despite of having some frictions in the course of the history of modern Nepal, there are only a few vicissitudes. Civil-military relations involve array of relationships between individuals, institutions, and interests, and Nepali Army has been able to keep its powder dry.

Nepali Army has to deal with multilateral challenges on the one hand, it is diverse and often conflicting nonmilitary men, institutions, and interests, on the other the politicians 
(Political-science-and-government/militaryaffairs, 2020, p. 71). Since last few decades, Nepali Army has also given exposures to the outside world besides essential human rights trainings. However, there might be an evidence of a gap, but Nepali Army is not a threat to Nepali people that it protects. Unlike in many Asian and African countries, Nepali Army has not toppled the democratic government or not done coup d'états, nor have they massacred the defeated army and people like in many wars elsewhere. However, it has always supported the rulers (be it the monarchs or rulers elected by people), and has maintained the chain of command. This would not be possible unless they had a good rapport with civils. Nepali Army, therefore, has to maintain itself into a politically neutral and professionally fighting machine (Brave Gurkhas) instead of being corrupt and greedy for power.

Fortunately, civil army divide is not a growing existential threat to Nepal's hardearned democracy. The history of Nepali Army began very long ago. After the launch of the campaign to unify Nepal, the need for a permanent army was felt at large. Nepali youths are known for honesty, bravery and conscientiousness that is not different while serving in Nepali Army. This fame led Nepali youths join the British Gurkha Regiment. Naturally, even the German Emperor William Kaiser was afraid of the Gurkhas.

\section{Methodology}

This is a qualitative research so the researcher has mainly used secondary data like journal articles, conference proceedings, and various documents of government, books, newspaper articles, magazine articles, and websites. Both the hardcopy and electronic resources have been consumed for gathering relevant information for this.

Writing a method section for a study for qualitative research partly requires educating readers as to the intent of qualitative research. It also includes mentioning specific designs, carefully reflecting on the role the researcher plays in the study, drawing from an everexpanding list of types of data sources, using specific protocols for recording data, analyzing the information through multiple steps of analysis, and mentioning approaches for documenting the accuracy — or validityof the data collected (Creswell \& Creswell, 2017 , p. 56). These meanings are varied and multiple, leading the researcher to look for the complexity of views rather than narrowing meanings into a few categories or ideas. This means even a single view may carry resonance of the truth.

Limitation of this study is that only available secondary data are extracted because it does not contain any primary data. Secondary data in social science disciplines such as sociology and economics is often used to answer complex questions of human behavior (NCBI, 2020, p. 5). The main purpose of this study is to find out how to foster Nepali Army and public relation better. Resultantly, Nepali Army can carry on the same or better service to Nepali and Nepal maximum.

\section{Conceptual Framework}

Pion-Berlin, D., \& Martínez, R., (2017). Military Reform, Civil - Military Relations, and Democratization. In Soldiers, Politicians, and Civilians: Reforming Civil-Military Relations in Democratic Latin America (pp. 1-12). Cambridge: Cambridge University Press.

Theory is changing so is a model. What is right and widely accepted now will be 
different or obsolete tomorrow. That applies in the military too. The study is specifically influenced by the Postmodern Military Model

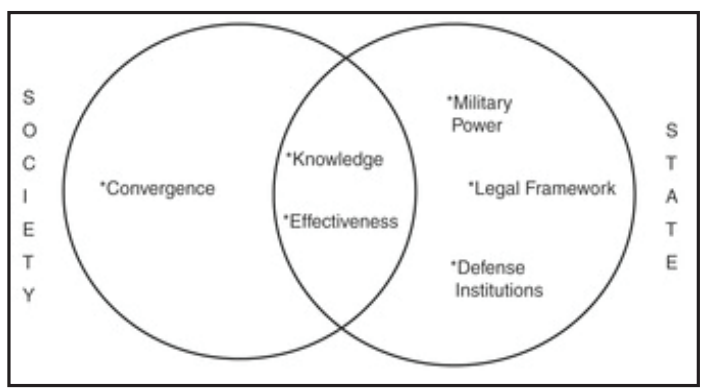

(PMMM). Charles Moskos was a leading army sociologist who argues that postmodern world is quite different from the previous times. Today's army is very different from the armies of the World Wars or Cold Wars. The paradigm has shifted towards newer focuses such as nuclear wars and terrorism. Be it the threats from the countries with nuclear plants or the terrorist organizations like Al-Qaida, Boko Haram and Islamic State, each causes severe threats to the society. An eye watering amount of the Budget of many countries have been mobilized to nullify the threats. Therefore, the need of new army model is widely felt and he developed the model by referencing the American Army, which is an exemplary one in the global village.

PMMM is promulgated by Moskos, other notable sociologists like Williams, and Segal claim, "That militaries faced with a shift from the threat perception of enemy invasion or nuclear attack to primarily nontraditional threats such as terrorism and ethnic violence undergo changes to their force structure, personnel requirements, and their relationship to the wider society (Karalekas, 2018, pp. 1140). Whether Nepali Army has been affected by this theory or not will be seen after analyzing the data.

\section{Analysis}

For this study, public-army rapports, inclusive policy adoption, and glorious history have been discussed below to find out how Nepali Army can foster relation with the Nepali people. Relation between civil and army has been good in Nepal for many centuries although they had a few abrasions in the course of making modern Nepal. Nepali Army has been trying to promote patriotism with their hard discipline. It is also about respecting and preserving national fundamental traditions, faiths, civilizations and cultures built on the sacrifices of history and historical ancestors. The army has been an integral part of the formation of modern states, and Nepal is no exception.

The unification of Nepal by King Prithivi Narayan Shah marked the beginning of the "formation" of modern Nepal, and the army's role was an integral part of that drive. To establish stability, patriotism, and national unity was the big challenges even after unification of modern Nepal. Similarly, the religion, culture, tradition, civilization, language, and dress of the people as a whole are invaluable ornaments of the society. Patriotism is also the task of protecting such issues of national importance.

\section{Public Army Relation}

Nepali Army, formerly Gurkha Army and the Royal Nepalese Army, is the land warfare force of Nepal that originated from Gorkha Kingdom (Nepali Army, 2020, p. 1). Nepali Army is one of the best armies of the world with a long glorious history. The nature of civil-army relations has to a large extent shaped the evolution of democracy in Nepal (Thapa \& Sharma, 2010, pp. 969-994). If so, this study discusses what kinds of relation it has been having with the public. 
According to a study, Nepali Army gives exposure to its soldiers to the outside world i.e. peace keeping operations and professional training so that they can further acculturate with democratic norms and values (KC, 2013, pp. 123-140). This indicates some problems exist in them. Who is ultimately at fault if a civil army gap exists? "One argument is that the gap may well be a failure in civic concern on the part of the citizen" (Snyder, 1984, pp. 108-146). Declining social capital is a possible cause for the civil army divide (Putnam, 2001, p. 7) in many parts of the world including Nepal.

The people do have the tendency to evaluate the needful reforms in military. Nepali Army has not earned the trust bestowed on it but merely receives it because of a lack of meaningful connection between Nepali Army and society. Civil army relations theory does not make a distinction about types of trust or how it is generated. A 1962 classic work by Samuel E. Finer, The Man on Horseback: The Role of the Nepal Army in Politics, explains the foundation of healthy civil army relations require society to trust and respect Nepali Army ( p. 45). Eric Noerdlinger theorizes in Armies in politics, when public perception of the Nepal Army is high, good civil army relations can occur (Nordlinger, 1977, p. 65), but he draws no distinction on the ability of the perception because discernment is a reality.

Relation between society and the Nepal Army are constantly on display. If anything, Nepali Army has become uncomfortable with the amount of connections being made to it (Horton, 2018, p. 34). Politicians, notably the sitting PM or Defense Minister, routinely try to invoke NA and draw it into the political realm (Burns, Baldor \& Superville, 2019, p.
50). There is no lack of conversation today surrounding Nepali Army and its role in the society.

Perhaps, it is not the army who has lost touch, but the society. Armies are reminded of their oath to serve. They are reminded of the cost when waving goodbye to family members. They know why they serve. It is society that needs the reminder. The "meaningful connection" is the social contract, otherwise known in our system as the Constitution. The citizens elect someone to speak on their behalf and represent their interests. These representatives must maintain an understanding of Nepali Army. They provide the oversight required for healthy CivilNepali Army relations.

Russell Weigley outlined the establishment of the army's unique culture from its earliest beginnings, through the Civil War era, to modern day. He suggested America sent its Army into the frontier so it would not be a threat to society. This fostered a unique culture "of discipline, virtue, responsibility" within the army but also contributed to its resentment of society (Weigley, 2001, p. 145). Nepali Army saw itself as the keeper of virtue and honor, which is often referred to as the starting point for the cause of the divide bitterness. A contemporary analysis by Mara Karlin argues, "The gap in civilian and army experiences. Since 9/11 has led to persuasive, persistent, and unrealistic myths that have eroded faith in civilian leadership of defense policy" (Karlin \& Friend, 2018, p. 30).

Luckily, despite the evidence of a gap, Nepali Army is not a menace to the society that it safeguards. Nor is there any sign it will be anytime soon. Nepali Army families leave their barracks and move into civilian communities and to live in harmony is 
already a common occurrence. However, previous researches highlighting any of Nepali Army's current efforts to connect with society is scanty. For example, Nepali Army's specific branch and most major commands have public engagement as a priority effort. Most units have partnerships with their local community.

They host Shivaratri, help in disasters, and pandemic like COVID19. "The majority of the professional force cannot remain silent" (Snyder, 1984, pp. 108-146). If they did speak, what would they say is tough? Few constraints prevent members of Nepali Army from criticizing their branch. Perhaps most of them adhere to the professional ethic advocated by Huntington. Perhaps they do abide by the discipline required to maintain good order and the trust of society. Nepali Army might have some degree of separation from society. This is the functional imperative of which Huntington spoke (Huntington, 1957, p. 88).

It is what makes the western model of civil army relations stronger over time. Snyder (1984, PP. 108-146) suggests the degree of separation is great. This is a convenient point often used to explain the gap but lacks merit. Nepali Army fixings are an important component of the ecosystem they belong to.

They employ civilians both on and off the installation, which suggests daily interactions between Nepali Army members and civilians. Nepal Army partners enroll their children in public institutions, they shop at local stores, they fill their petrol tanks, they join civic groups, they meet people at local parks, and they join temple-going groups. These entire activities help close the civil- army gap. Their bases are necessary for the functioning of it. The idea that they are islands unattached to society is unsupported by reality in the Nepali contexts.

Nepali Army has earned the trust of its citizens. The people have given up some liberties in exchange for security. Under a well-established concept, Nepali Army has secured the inalienable rights of life, liberty, and property, so much so that the country is the most sought by the tourists. Nepali Army has protected Nepal and Nepalis at great personal costs.

Even if the Nepal Army were to implement reforms, the citizenry would be required to listen and digest the Nepal Army's transparency. Unless this transparency is splashed across social media, it is unlikely to be consumed, but will invariably lower trust. The army cannot mobilize society to care (Rosen stone \& Hansen, 1993, p. 98). It can, however, continue to execute its duty and keep society safe enough to have these discussions.

\section{Change in Policy}

Nepali Army has been trying to promote patriotism with their hard discipline. The army has been an integral part of the formation of modern states, and Nepal is no exception. The unification of Nepal by the King Prithivi Narayan Shah marked the beginning of the "formation" of modern Nepal, and the army's role was an integral part of that drive.

After the unification of the tiny states, constructing a national identity under a defined system of governance, which unites all the citizens and ensures political stability and viability, was one of the major challenges. Similarly, the religion, culture, tradition, civilization, language, and dress of the people as a whole are invaluable ornaments of the 
society. Patriotisms also the task of protecting such issues of national importance.

Patriotism awakened from the undulating aspect of national sentiment. The people as a whole must establish national unity, belonging, importance and self-respect among themselves. The strong foundation of patriotisms is the nationalist element. The true nationalist is selfless and sacrifice towards the nation as shown by Nepali Army. Patriotism can be established only through the unity of the people and the spirit of patriotism as it refers to the overall ideological philosophy, ideas and ideals in favor of the nation's independence, self-respect, independence, integrity and sovereignty. It is a nationalist ideology to focus on the issues inherent in the national environment and to balance all parties on an equal basis and use it for the overall national interest.

Civil army divide is not a growing existential threat to Nepal's democracy. A gap has existed since the nation's founding and is an inherent part. The strength and commitment of civilian control result from the active and sustained commitment of both civilians and Nepali Army professionals to an idea that had proven itself in good times and bad. Nepali Army has not forgotten this motto. Moreover, it has been trying to bring changes to cope with existing challenges.

The Directorate of Human Rights (DHR) was established as the Human Rights Cell on July 8, 2002 and in 2005, and later on, it was converted into the Directorate. Besides, the Nepalese Army has integrated the teaching of IHRL and IHL into all army career courses. Addition to its commitment, in compliance to the Nepalese Law, which states that $45 \%$ of all vacant government positions be reserved for excluded groups, the Army in 2006, amended its Army Act. After which, out of the $45 \%$ reserved position within the Nepal Army $20 \%$ is reserved for women, $32 \%$ for Janajati, 28\% for Madheshi, 15\% for Dalit and 5\% for remote regions (Nepali Army, 2020, p. 2).

Since the abolition of monarchy in 2008, efforts are mainly focused on 'restructuring the state a major component of which is security reform. There is little indication that the proposed reforms would be implemented because major parliamentary political parties look upon the Army to stem the rapidly expanding Maoist organization and influence across the country while the Maoists themselves want their People's Liberation Army assimilated into the national army (Thapa \& Sharma, 2010, pp. 969-994). Nepal became a member of the United Nations in 1955 since then, it has been an active participant of most UN peace operations in different parts of the world. Besides providing security of the country, Nepali Army has been involved in several national development, nature conservation and disaster management.

Nepali Army has been the main contributor to the development of sports in Nepal in addition to broadcasting TV and Radio programs through different channels. For Nepali Army, their experiences are sound enough to highlight the importance of civil army relations. With the promulgation of the new constitution, new criteria have come into the force for Nepal Army to be in greater civilian control (Spotlight, 2019, p. 2). Advocating Civil Army Relations (CMR), Huntington developed the objective of civilian control theory, encouraging professionalism of the forces and subjective control for the autonomous run of their institution. 
Janowitz tried to minimize the difference between objective and subjective controls by defending army effectiveness and democratic civilian control, whereas Haltiner pursued political-army theory based on civil, army, and citizenry elements, reducing recruitments in mass (Pathak \& Uprety, 2011, p. 6). Theoretically, Nepali Army seems to be guided by these philosophies too.

\section{One of the Oldest Armies}

Nepali Army has been great guns so has been very brave. Though we do know much about public army relation in ancient times, it existed many centuries ago. Nepal had also maintained her army strength according to documents of the reigns of prominent Lichchavi kings, including Mandev, Shiva Dev, Narendra Dev and Anshuvarma (Nepali Army, 2020, p. 2).

Nepali Army, whether serving this country or in the army of foreign countries, has earned the reputation of being very brave and dutiful for their honesty, duty and selfless service. At some point in the wars including the First and the Second World Wars, when Nepali Army was advancing as Gurkha, that approaching made the enemy's heart tremble with extreme fear. This is the reality and pride of Nepali Army history. They are ready to sacrifice their lives but do not escape. This is the main mantra Nepali Army does have even today.

Nepali Army is a primogenital organization with a glorious past in Nepal. The history of Nepali Army begins with the olden times of a sovereign country, Nepal. With its own characteristics, over time, this organization has transformed and modified itself to become Nepali Army today. Since the beginning of its history, it has earned the highest reputation by following the orders of the government, being diligent, loyal, patriotic and dutiful to the motherland whoever were in power.

It is reported that Nepali Army earlier consisted of only infantry, cavalry and elephant armies. In the fifth century, infantry and elephant armies were used to suppress the rebellious feudal lords across the west, while in the eighth century, Nepali cavalry showed its dexterity in northern India. This shows that the Nepal Army work of ancient Nepal was estimable. From ancient times the three types of armies have undergone political changes in the middle Ages as well as Nepal Army practices. During that period, the practice of mobilizing the youth of a state on the basis of need appeared on the basis of public participation replaced a permanent army.

The youth were trained to use the weapons like - swords, spears, knives, daggers, bows and arrows, etc. When in need, the required number of youths were called from each house and mobilized in the war. By the middle Ages, royal hostilities, feudal wars between divided states, and foreign invasions had influenced the army organization in each state. However, the permanent army was not organized.

At that time, young people were allowed army training and weapon training. Weapons were collected and kept in various temples and monasteries. In times of crisis, ordinary people would gather by ringing bells or whistles, those who had weapons would bring them themselves, and those who did not would get from the government stored in temples, monasteries or forts. Thus, in the middle Ages, the state was protected on the basis of public participation without a permanent army. 
In the middle ages, however, Nepali Army's operation began to generate income. There were three kingdoms - the Khas Malla kingdom from Trishuli to Kumaon-Garhwal, Nepal Mandal kingdom in the hilly region from Trishuli to Koshi, and the Karnavanshi kingdom ruled by Simrongadh, situated between the Mahabharata to Bodhgaya and Ganga to the south, Koshi to the east and Gandaki river to the west. Even in those states, especially in the affluent Nepal Mandal state, the Kathmandu Valley had to face many attacks due to quarrels between the ruling families.

The attackers were sent back with ample property. As a result of such incidents, militarization began. In particular, the Khas Malla state made a special contribution to Nepali nation by the Khas language (former form of the present Nepali language) and militarization. The Khas Malla Empire was established because of its strong army power.

At the end of the pre-medieval period, the Khas Malla and Karnatavanshi states ended, and Nepal was further divided. There were 52 states, including the state and East Sen. As a result, the states could not keep a strong and active army like before. Among the states of the time, especially the Newar Malla states were engaged in the promotion of religion, culture and art. The Nepal Army side relied on public participation.

After the launch of the campaign to unify Nepal under the leadership of King Prithvi Narayan Shah of Gorkha, the need for a permanent army was felt. Therefore, Prithvi Narayan Shah in 1819 established five companies by dropping the bombshell. This act has been proved a milestone in Nepal's Nepal Army history from various angles.
Permanently established armies began to appear more talented and influential than based on public participation. Therefore, the rulers adopted a policy of keeping the permanent army. Such a policy was adopted by King Jayaprakash Malla of Kantipur and King Prithvi Narayan Shah of Gorkha. Later, by winning the Malla dynasty, Prithvi Narayan Shah embarked on a policy of uniting the divided country. When he consulted his uncle, Prince Udyot Sen of Palpa, about which castes would be suitable for the permanent army, the latter advised that it would be appropriate to give priority to the Khash caste. However, he proved the latter wrong as the King Prithvi Narayan Shah recruited people of all castes in his state.

\section{The Rise of Gurkhas}

Nepali Army has been more than one string on its bow. During the reign of the King Ran Bahadur, the people of the defeated kingdom were also included in the army sent to attack the twenty-two kingdoms. The history of the world has proved that any nation is dedicated to defend her. Only those who are strong and talented from a Nepal Army point of view can achieve victory.

There is a saying about ancient and medieval Nepal Army history and strategy: in war, civilized races are won by an uncivilized and ruthless race. Cultured and civilized people are not ruthless; they do not resort to killing. Rude people are ruthless and kill for their own benefit. However, in reality, the race that is perfect in the history of the development of human society is the one that is victorious.

In the history of Nepal, the way in which the king Prithvi Narayan Shah and his successors diligently mastered the art of warfare and strategy resulted in the success of the Gorkhali 
army. Three Newar Malla kings fought in the battle of Bhaktapur were defeated totally around 1826. The Shah Kings also enlisted the youth of the defeated region in their army. During the same period, Nepali Army defeated many powerful foreign Generals in Nepali-Tibet-China War. Achieving bravery, courage and success, Nepali Army continued to advance. "Better to die than be a coward" is the motto of the world-famous Nepali Gurkha soldiers who are an integral part of the British Army (BBC, 2010, p. 3).

As Prithvi Narayan Shah adopted a policy of promotion based on bravery, tactics and efficiency shown in the war, Nepali Army was gaining efficiency and success. Napoleon Bonaparte in France adopted such a policy, but in Nepal, after Bhimsen Thapa became the Mukhtiar and General, the post of General and Colonel was confined to his family. Kampu and Paltan were also subordinated to his father, brother and nephews.

After the Kot Prava, the Rana family emerged and the policy of promotion in the army was radically changed. Again, the Rana rulers maintained the sole authority of their own family in high Nepali Army positions. Resultantly, there was no proportional development in Nepali Army later. Moreover, after third Nepal - Bhot War, Nepal did not have to take part in any external wars.

On the other hand, Nepali youths recruited in foreign armies never hesitated to carry out their duties in the assigned battlefield with great restraint. They earned a reputation in the Nepal Army history of the world especially for honesty, bravery and conscientiousness while serving in the British Gurkha Regiment. Even the German Emperor William Kaiser was afraid of the Gurkhas. Due to the bravery and influence shown by Nepali Army in the First World War, then Nepali Prime Minister Judda Shamsher was awarded medals from many mighty countries of the world.

The British Empire awarded the 'Victoria Cross' to the Gurkha Army for its unparalleled bravery and courage in various battles. Similarly, the warriors fighting in Nepali Army were awarded the 'Nepal Army Cross'. Nepal had provided Nepali Army assistance to East India Company when it was in trouble. During the Indo-Pakistani war in 1965, the armies of the Gorkhali Army in India fearlessly participated in the battlefield, sacrificing their lives and showing admiration for their duty. They also played a commendable role in the Falklands, Iraq and Afghanistan wars. In this way, Nepali Army showed great courage, prowess, bravery and warlike skills in different battlefields of the world and identified Nepal as the Land of the Brave Gorkhalis. Since those in power did not allow Nepali youths to earn a living in the country, they never betrayed the service of foreigners.

There has been an uninterrupted relationship of mistrust and suspicion between the political leadership and the army since the very first democratic opening in 1951 AD. The political leadership, including now abolished monarchy, was never interested in promoting a politically neutral and professional national army. Neither the monarchy nor the political leadership, which used the Army for serving their narrow short-term political goals (Thapa \& Sharma, 2010, pp. 969-994), although closely identified as loyal to the monarchy, owned Nepali Army.

Despite different contexts and rulers, it is reported that Nepali Army has been trying to play a great responsibility to bridge the 
civil- army divide so the divide seems trifling in Nepal. However, there have been some frictions. The perspectives on how to resolve this friction point is essential. However, the Civil Army divide is not an existential threat as assumed widely. The beauty of the Civil Army relations system is its closeness. Some critics offer commentary on abrasions of Civil Army relations theory and often portray few unhealthy Civil Army interactions.

The post conflict (especially during the Maoists'-led government period) civilarmy relations in Nepal developed towards confrontation when the Maoists talked openly about launching of an October Revolution, establishing People's Republic in Nepal, and integrating all the Maoist combatants into Nepali Army (KC, 2013, pp. 123-140). However, it turned into a different or safer settlement.

The problem is that civilian trust in Nepali Army institution is becoming meaningless because of civilians' lack of understanding of it and its acceptance of that trust as confirmation of its efforts. Therefore, the onus is on Nepali Army to be far more critical of itself than the public. Another possibility not taken into consideration is Nepali Army could be doing the right thing. Nepali Army services have been transparent in recent years regarding armies' misconduct. This effort has continued despite trends suggesting no change in behavioral trends.

\section{Conclusions}

Nepali Army is the knight in the shining armor. Relation between society and Nepali Army is constantly on display. Rapports between civil and Nepali Army may not be excellent nor bad but good. In Nepal for many centuries despite having some brushings in the course of the history of modern Nepal, there are difficulties. Nepali Army should give to expose its soldiers to the outside world besides essential human rights trainings. Despite the evidence of a gap, Nepali Army is not a danger to the society that it protects.

Civil army divide is not a growing existential threat to Nepal's democracy. The history of Nepali Army started with the olden times of a self-governing Nepal. After the launch of the campaign to unify Nepal under the leadership of the King Prithvi Narayan Shah, the need for a permanent army was felt. Gradually, they earned a reputation in the Nepal Army history of the world especially for honesty, bravery and conscientiousness while serving in the British Gurkha Regiment. Even the German Emperor William Kaiser was afraid of the Gurkhas.

Unlike in many Asian and African countries, Nepali Army has not toppled the government or not done coup d'états nor have they massacred the defeated army and people like in many wars elsewhere. However, it has always supported the rulers (be it the monarchs or rulers elected by people) and has maintained the chain of command being in lock and load. This would not be possible unless they had a good rapport with the civils. Nepali Army, therefore, has to maintain broader transformation into a politically neutral and professionally fighting machine (Brave Gurkhas) instead of being corrupt and greedy for power. 


\section{References}

Answering developmental questions using secondary data. (1, December). Retrieved from https://www.ncbi.nlm.nih.gov/pmc/ articles/PMC4724430/

BBC (2010). Who are the Gurkhas? Retrieved from https://www.bbc.com/news/uk10782099

Burns, R., Baldor, L., and Superville, D. (2019). Trump touts July 4 army salute critics. Army Times.

Creswell, J. W. and Creswell, J. D. (2017). Research design: Qualitative, quantitative, and mixed methods approaches. Sage publications.

Finer, S. D. (1962). The man on horseback: The role of the army in politics. Praeger.

Horton, A. (2019). Pentagon tells white house: Keep politics away from the Army. Washington Post.

Huntington, S. R. (1957). The Soldier and the state: The theory and politics of civil-army relations. Harvard University Press.

Karalekas, D. (2018), "Moskos's Postmodern Military Model", Civil-Military Relations in Taiwan, Emerald Publishing Limited, pp. 1140.

Karlin, M. and Friend, A. (2018). Army worship hurts U.S. democracy: Battlefield experience should not Trump the outsider benefits of civilian leadership. Foreign Policy.

KC, K. (2013). Historical analysis of civil-army relations in Nepal. Tribhuvan University Journal, 28 (2), pp. 123-140.
Nepali Army. (2020). Nepali Army. Retrieved from https://www.nepalarmy.mil.np

Nordlinger, E. A. (1997). Soldiers in politics: Army coups and governments. Prentice Hall.

Pathak, B. and Uprety, S. (2011). Civil-army relations: Theories to practices. PCS Center.

Putnam, R. D. (2001). The collapse and revival of American community. Simon and Schuster.

Rosenstone, S. J. and Hansen, J. (1993). Mobilization, Participation, and Democracy in America. Macmillan.

Ruxton, C. (2016). Tea: Hydration and other health benefits. Primary Health Care, 26(8), pp. 34-42. https://doi.org/10.7748/phc.2016. e1162

Spotlight (Feb. 9, 2019). Civil army relations Nepali perspective. Spotlight. Retrieved from https://www.spotlightnepal.com/2019/02/09/ civil-army-relations-nepali-perspective/

Snyder, J. (1984). Civil-army relations and the cult of the offensive, 1914 and 1984. International Security, 9 (1), pp. 108-146.

Thapa, G. B. and Sharma, J. ( 2010). Democracy building and changing role of the Nepal army. The Indian Journal of Political Science, 71 ( 3 ), pp. 969-994.

Trask. D. (997). Democracy and defense: Civilian control of the army in the United States. Issues of Democracy, 2 (3).

Weigley, R. F. (2001). The American civil-army cultural gap: A historical perspective, colonial times to the present, in Soldiers and Civilians: The Civil-Army Gap and American National Security (Ed. Peter D. Feaver and Richard Kohns). MIT Press. 